\title{
The Influence of Hedonic and Utilitarian Shopping Value Towards Consumer Behavioral Intention Among Youth Mall Shoppers
}

\author{
Norlaile Salleh Hudin ${ }^{1}$, Nur Shafiqa Azrin Khairil Annuar ${ }^{1}$ \& Ahmad Zainal Abidin Abd Razak ${ }^{1}$ \\ ${ }^{1}$ Department of Business Management and Entrepreneurship, Universiti Pendidikan Sultan Idris, Perak, Malaysia \\ Correspondence: Ahmad Zainal Abidin Abd Razak, School of Management, Department of Business Management \\ and Entrepreneurship, Universiti Pendidikan Sultan Idris, Perak, Malaysia. Tel: 60-15-4789-7773. E-mail: \\ ahmad.zainal@fpe.upsi.edu.my
}

Received: October 10, 2019

Accepted: November 5, 2019

Online Published: December 23, 2019

doi:10.5430/rwe.v10n5p1

URL: https://doi.org/10.5430/rwe.v10n5p1

\begin{abstract}
In the past decade, considerable amount of researches investigated the influence of hedonic and utilitarian shopping values on consumer behavioral intention. Accordingly, this has driven the current study to achieve its objective which is to determine the influence of hedonic and utilitarian shopping values on consumer consumer behavioral intention among youth in Malaysia. Embarking on the quantitative methodology, a survey is conducted among 469 university students who enrolled to a compulsory university course. The results showed that hedonic and utilitarian shopping values had positive influence on the youth consumer behavioral intention. This implies that shopping mall developers should consider hedonic and utilitarian preferences in terms of the design, selection of stores and functionality in creating a shopping mall particularly in serving youth market segment.
\end{abstract}

Keywords: Hedonic, utilitarian, shopping values, consumer behavioral intention, youth, shopping mall

\section{Introduction}

The growth in economics and changes in social had created gradual shifts in how consumers make their purchases. Small-scale traditional shops which used to be the main shopping centers were replaced by modern and organized retail shops (Erkip \& Ozuduru, 2015). Despite that, modern shopping malls are rapidly threaten by the development of online shopping platforms which do not require customers to step out of their comfort homes to make purchases (Calvo-Porral \& Lévy-Mangin, 2019) and booming numbers of organized shopping malls (Parakhonyak \& Titova, 2018).

On a similar subject, issues on how shopping malls strategize in dealing with this rapid business competition had attracted considerable numbers of scholars to conduct extended studies. For example, Chung (2015) carried out an investigation on utilitarian and hedonic shopping values of airport shopping malls' customers, whereas Bakirtas, Bakirtas and Cetin (2015) attempted to determine whether the hedonic and utilitarian factors contributed to customers' satisfaction towards a conventional shopping mall. Meanwhile, Vukadin, Wongkitrungrueng and Assarut (2018) examined the artistic effects of customer shopping value including utilitarian and hedonic symbolic towards customer behavioral intention in an artistic shopping mall, whereas Kesari and Atulkar (2016) measured the hedonic and shopping values of customers in shopping malls located in smaller cities. On the other hands, Allard, Babin and Chebat (2009) studied the influence of mall visitors' income towards hedonic and utilitarian orientations.

The results of these studies led to a conclusion that different types of strategies should be developed for specific types of market. In the case of the current study, specific market refers to the Malaysians, who have a particular buying behavior for instance higher income Malaysian mall visitors preferred malls with green features compared to business or seating features (Hami, Fazle, \& Emami, 2016). Malls with green features display more plants and trees around the shopping areas rather than business and seating features which offer higher assortment of stores and more seating areas for relaxation. Moreoer, although Malaysian mall visitors' satisfaction were found higher and consistent with other studies due to variety of choices of diners and entertainment activities offered (Albattat, Yajid, \& Khatibi, 2019; Said, Gambo, \& Ismail, 2016), they ranked higher preference towards shopping malls which have worshipping place (Said, et al., 2016; Onuoha, Umoh, \& Ufomba 2017; Schouten, 2019).

The results of the previous studies concluded the Malaysian shopping malls' visitors' uniqueness. Furthermore, it is 
crucial to note that local researchers paid less attention in investigating the influence of age of the mall visitors towards their consumer behavioral intention considering scant evidence in this area. To authors' knowledge, only Hami et al. (2016) measured the differences between older and younger mall visitors' in terms of their shopping mall preferences. Also, the past researches were limited by particular shopping malls only. In more precise, Chung (2015), Allard et. al (2009), Kaihatu and Spence (2016), Vukadin et al. (2018), and Kesari and Atulkar (2016) considered visitors at only one or two malls, implying the lack of comprehensiveness of their samples. Therefore, the aim of this study is to determine the influence of hedonic and utilitarian shopping values towards consumer behavioral intentions of youth particularly in diverse shopping malls in Malaysia.

It should be noted that the current research is driven by the following factors; (1) the inconsistencies of findings about shopping mall consumer behavioral intention, (2) the scant evidence related to Malaysian youth consumer behavioral intention, and (3) the narrow scope of only one or two shopping mall in previous studies. The current study is deemed important because it aims to examine the specific youth market in an attempt to shed light to scholars in this field. More importantly, this study attempts to fill in loopholes in the current literature of marketing, and supply scientific inputs for better decision making in developing business strategies for shopping malls.

In a further extend, this study has proven to be able to extend the present knowledge in few angels. First, this research is expected to produce new findings on the Malaysian youth consumer behavioral intention. It is worth to note that past researchers did not take the influence of age into account when they designed their works (Bakirtas, et al., 2015; Chung, 2015; Kesari \& Atulkar, 2016), the lack of focus on Malaysian context (Budisantoso, Bhati, Bradshaw, \& Tang, 2016; Dalziel \& Bevan-Dye, 2018), and contrasting evidences in earlier studies (Chebat, Michon, Haj-Salem, \& Oliveira, 2014; El Hedhli, Zourrig, \& Chebat, 2016; El Hedhli, Zourrig, \& Park, 2017; Elizabeth Lloyd, YK Chan, SC Yip, \& Chan, 2014; Prashar, Singh, Parsad, \& Vijay, 2017). Second, local researches had investigated about shopping malls' visitors, however the studies are deemed inadequate because the work of Alavi, Rezaui, Valaei and Wan Ismail (2016) and Hami et. al (2016) were concentrating on shopping malls in Kuala Lumpur only. For that reason, the current study will be substantially valuable as the data can be generalized to overall Malaysian setting. More importantly, the sampling technique used in this study enables the inclusion of shopping mall visitors from all over Malaysia.

\subsection{Consumer Behavioral Intention}

Consumer behavioral intention has been vigorously studied in the field of marketing. It has been measured as patronage intention (El Hedhli, et al., 2017), the inclination of consumers towards coming back to the stores or shopping malls they went. In addition, consumer behavioral intention also constitutes the word-of-mouth which flow from a satisfied customer to others (El Hedhli, et al., 2016; Hana Afifah \& Norlaile Salleh Hudin, 2017, 2018). A satisfied consumer typically spreads good words about his/her good experiences in purchasing and influences others to encounter similar purchase. Similarly, Bakirtas et. al (2015) defined consumer behavioral intention as repatronage intention and service recommendation.

\subsection{Characteristics of the Malaysian Youth and Their Buying Behavior}

Youth are the generation born in 1988-1998 (Manwaluddin, Teng, Johari, Baharudin, \& Suhaimi, 2018). There are 8.18 million individuals aged between 20-34 in Malaysia (Institut Penyelidikan Belia Malaysia, 2019). Malaysian youth considered involvement in games, participating in enjoyable activities and going on vacations were important to support their well-being, although they also thought that having significant amount of savings, free from debts and living in luxury homes were crucial in defining quality lives (Waheed,et al., 2017; Mohamed, D'Silva, Samah, Shafril, \& Dahalan, 2018). In terms of eating out, Malaysian youth were inclined to go to restaurants which offered cozy ambience, decorated aesthetically and provided Wifi connection (Jalil, Fikry, \& Zainuddin, 2016). Ramlan, Nga, Idris and Jinideh (2018) explained that 54.5\% of Malaysian youth that they investigated claimed that they always plan their monthly spending, compared to only $40.8 \%$ who occasionally make monthly spending plan. Despite that, further evidence showed that they were willing to spend more on products that they perceived of high values (Lim, Ramli, Yusof, \& Cheah, 2015). On regards to the expenditures related to self-care, Malaysian youth spent about $3.6 \%-31.6 \%$ of their monthly income for it (Ramlan, et al., 2018). Although $67.3 \%$ of youth were able to afford their own daily food expenses, $26.7 \%$ were not (Ramlan, et al., 2018).

\subsection{Hedonic and Utilitarian Shopping Values}

Hedonic and utilitarian shopping values are two ends of a spectrum. At one end, hedonic shopping value represents an entertaining and enjoyable experience during shopping (Babin, Darden, \& Griffin, 1994). In addition, hedonic shopping value had been linked to fantasy, multisensory, and emotive aspects of a customer's experience with a 
product (Hirschman \& Holbrook, 1982). Customers who inclined towards hedonic value perceived shopping as escapism as they did not see shopping as a chore (Elizabeth Lloyd, et al., 2014). They tend to communicate the emotional worth to others and loyal to the enjoyable experience (Babin, et al., 1994). Hedonic shoppers go on a shopping trip to release stress and keep up with the latest trend (Evangelista, Low, \& Nguyen, 2019).

At the other end of the scpectrum, utilitarian shopping value indicates the appreciation towards practical, functional and instrumental shopping experience (Babin, et al., 1994). Utilitarian consumers appreciate value for their purchases that comes with monetary saving, customized products and convenience (Kesari \& Atulkar, 2016; Mejdoub, \& Arab, 2017). They also achieve higher level of satisfaction when they made an efficient and purposeful purchase in less time (Davis, Smith, \& Lang, 2017). Discussing about the context of a shopping mall, easy access to shopping areas and good navigation of a mall attracts the utilitarian shoppers (Rahman, Wong, \& Yu, 2016). For that reasons, a utilitarian shoppers preferred traditional markets where they could make their purchase fast in good price, and required less travel time to save travelling cost (Evangelista, et al., 2019; Kumaraswamy, Ebrahim and Wan Mohammad, 2019).

\subsection{Effect of Hedonic and Utilitarian Shopping Values on Consumer Behavioral Intention}

Earlier studies concluded that hedonic value had significant influence on mall patronage intention (El Hedhli, et al., 2017; Michon, Chebat, Yu, \& Lemarié, 2015). Moreover, hedonic value has been found to increase customer satisfaction (Chebat, et al., 2014; Kesari \& Atulkar, 2016), and led to positive word-of-mouth (El Hedhli, et al., 2016). Thus, the hypothesis below is constructed.

$\mathrm{H}_{1}$ : Hedonic shopping value has significant influence on consumer behavioral intention

Number of studies attempted to examine the influence of utilitarian shopping value towards consumer behavioral intention. Hedhli et. al (2017) and Michon et. al (2015) confirmed that utilitarian shopping value resulted in significant effect on mall patronage intention. In further support, Kesari and Altukar (2016) found positive influence of utilitarian shopping value on customer satisfaction. However, contrasting evidence were found by past studies which explained that utilitarian shopping value failed to influence positive word-of-mouth (El Hedhli, et al., 2016), and had less contribution towards customer satisfaction (Chebat, et al., 2014; Rusomyo, Junlin, \& Mangare, 2017). Despite that, a study in Asian market revealed that there were more utilitarian compared to hedonic shoppers (Prashar, et al., 2017). Considering the focus of the present study on the youth and Asian market, the subsequent hypothesis is developed.

H2: Utilitarian shopping value has significant influence on consumer behavioral intention

\section{Method}

\subsection{Participants}

This research embarked on a quantitative methodology where the main data collection technique is through survey. In this study, $77.2 \%$ of the respondents were female. Meanwhile, in terms of the age, the mean was 21 years old and their monthly income/pocket money was RM873.96. Out of 534 of questionnaires received, 63 of them stated that they went to the shopping trip more than 2 months ago. These data were excluded from the sample due to the assumption that the attempt to recall their shopping experiences which occurred more than 2 months before may no longer be accurate. Overall, 469 of responses were usable for the data analysis.

\subsection{Procedures}

This cross-sectional survey took up two days to be completed in the month of September 2019. A cluster sampling technique was adopted in this study in which out of 18 groups of undergraduate students who took a compulsory university course, 4 groups were randomly selected. The students enrolled in this university course were selected as the sampling frame because of the similarities in the characteristics of youth Malaysian mall shoppers considering their age and the geographical distribution of the shopping malls they went. Morever, they also came from diverse academic background, thus were more representative of the population. Most of the earlier studies conducted mall intercept whereby the age factor was less controllable, and were concentrated on a specific mall format (Alavi, et al., 2016; El Hedhli, et al., 2016; El Hedhli, et al., 2017; Kesari \& Atulkar, 2016).

Initially, the lead researcher contacted the course intructors to gain permission to conduct the survey after the lessons ended. Upon gaining their approval, an enumerator was trained to administer the survey to the respondents. The survey had taken place in the lecture halls for about 10 minutes for each session. 


\subsubsection{Sample Size}

The sample frame for the current study consisted of 2,761 data, thus minimum 338 responses must be gathered (Krejcie \& Morgan, 1970). The same suggested sample size was also proposed through the calculation ran by Raosoft sample size calculator. Since the class size was about 130 students each, originally about 3 classes were selected randomly. However, considering the technical aspects for data analysis such as missing values and unreliable responses, 5 classes were randomly selected and a total of 469 usable responses were collected eventually.

\subsubsection{Measures}

The research instrument used in this study was adopted from Bakirtas et al. (2015) due to the clarity and simplicity of the wording of the items. This consideration had been taken based on the feedback of the course instructors who explained the lower engagement of their students when dealing with long and complexed questions. Therefore, to ensure that respondents complete the survey in 10 minutes, the instrument developed by Bakirtas et al. (2015) was selected. It contained four sections; (1) demographic information (age, gender, income), (2) hedonic shopping values (5 items), (3) utilitarian shopping value ( 2 items), and (4) behavioral intention ( 2 items). Respondents would be able to show their responses based on 7-Likert scale ranging from 1-strongly disagree to 7-strongly agree.

A pilot study was conducted based on 30 data collected earlier among youth to determine the reliability of the instruments for the actual data collection. For hedonic shopping value, the Cronbach alpha value obtained was 0.832, while for utilitarian shopping values the Cronbach alpha value was 0.672 . The reliability of the utilitarian shopping value did not reach the minimum recommended value of 0.7 (Nunnally, 1978) due to its small number of corresponding items, however was consistent with earlier studies which obtained less than 0.7 Cronbach alpha value (Stoel, Wickliffe, \& Lee, 2004) and align with the recommendation of Hair, Black, Babin and Rolph (2014). One item (related to enjoyable time spent shopping) was deleted from the hedonic shopping value as suggested by the analysis and increased the Cronbach alpha value to 0.834 .

\subsubsection{Data Analysis}

The data collected were analyzed by using multiple regression analysis in SPSS 26. The descriptive analysis particularly percentage and mean were employed to describe the sample of this research while multiple regression analysis was executed to determine the influence of hedonic and utilitarian shopping values on Malaysian youth consumer behavioral intention in shopping malls.

\section{Results}

The explanation in this section focuses on the objective of the current study which is to determine the influence of hedonic and utilitarian shopping values on Malaysian youth consumer behavioral intention in shopping malls. Table 1 reports the results of the descriptive analysis. It shows that hedonic shopping value, utilitarian shopping value and consumer behavioral intention obtained the mean of 5.3273, 5.1023 and 5.5096 respectively.

On the other hands, Table 2 depicts the summary of a good fit regression model $(p=0.000)$ which was developed based on 469 data collected. It indicates an $R$-square value of 0.510 . In table 3, the multiple regression results are displayed. The dependent variable was consumer behavioral intention and the independent variables were hedonic shopping value and utilitarian shopping value. The present research hypothesized that the dependent variables have positive effect on consumer behavioral intention. It reveals that hedonic shopping value $(\beta=0.519, p=0.0000, \alpha=0.05)$ and utilitarian shopping value $(\beta=0.323, p=0.0000, \alpha=0.05)$ significantly influence consumer behavioral intention. Therefore, $\mathrm{H}_{1}$ and $\mathrm{H}_{2}$ are supported.

Table 1. Descriptive analysis results

\begin{tabular}{lrrr}
\hline & $\mathrm{N}$ & \multicolumn{1}{c}{ Mean } & Std. Deviation \\
\hline Hedonic & 469 & 5.3273 & 1.11625 \\
Behavioral_intention & 469 & 5.5096 & 1.15628 \\
Utilitarian & 469 & 5.1023 & 1.21211 \\
Valid N (listwise) & 469 & & \\
\hline
\end{tabular}


Table 2. Model summary

\begin{tabular}{lrrrr}
\hline Model & R & R Square & $\begin{array}{c}\text { Adjusted R } \\
\text { Square }\end{array}$ & \multicolumn{1}{c}{$\begin{array}{c}\text { Std. Error of the } \\
\text { Estimate }\end{array}$} \\
\hline 1 & $.714^{\mathrm{a}}$ & .510 & .508 & .81113 \\
\hline
\end{tabular}

Table 3. Multiple regression results

\begin{tabular}{|c|c|c|c|c|c|c|}
\hline \multirow[b]{2}{*}{ Mod } & & \multicolumn{2}{|c|}{ Unstandardized Coefficients } & $\begin{array}{l}\text { Standardized } \\
\text { Coefficients }\end{array}$ & \multirow[b]{2}{*}{$\mathrm{t}$} & \multirow[b]{2}{*}{ Sig. } \\
\hline & & $\mathrm{B}$ & Std. Error & Beta & & \\
\hline \multirow[t]{3}{*}{1} & (Constant) & 1.096 & .204 & & 5.377 & .000 \\
\hline & Utilitarian & .323 & .034 & .339 & 9.463 & .000 \\
\hline & Hedonic & .519 & .037 & .501 & 13.974 & .000 \\
\hline
\end{tabular}

\section{Discussion}

The current research attempts to determine the influence of hedonic and utilitarian shopping values on consumer consumer behavioral intention among youth in Malaysia. The results show that hedonic and utilitarian shopping values have positive influence on consumer behavioral intention which bolstered the findings from earlier researchers (Bakirtas, et al., 2015; El Hedhli, et al., 2016; El Hedhli, et al., 2017). In the context of Malaysian youth, it is not surprising to find the hedonic shopping value determining their consumer behavioral intention considering the evidence that Malaysian youth have high preference towards participating in enjoyable activities (Mohamed, et al., 2018). Satisfaction with the service led them to positive word-of-mouth (Hana Afifah \& Norlaile Salleh Hudin, 2018). Relating this finding to the current research, shopping trip is seen by the youth as an opportunity to escape, leisure and enjoy their free time (Calvo-Porral \& Lévy-Mangin, 2019). Furthermore, since all the respondents were students who were just went through a transition from adolescents to independent young adults, they became more financially independent, resulting in higher expenditure capacity and allow larger expenditure to occur compared to when they were just adolescents (Pentecost, Donoghue, \& Thaichon, 2019).

This study also corroborates with Hedlhi et. al (2017) that utilitarian shopping value play a significant role in consumer behavioral intention. This substantiates earlier works by Michon et. al (2015) and Bakirtas et. al (2015) with the expension of knowledge about youth market segment. Previously, Michon et. al (2015) and Bakirtas et. al (2015) ignored the effect of age on consumer behavioral intention. In conjunction with the Malaysian youth, Ramlan et. al (2018) purported that majority of Malaysian youth that they investigated prepared monthly spending plan, thus this evidence implies the positive effect of utilitarian shopping value on youth consumer behavioral intention. Moreover, most of the respondents who were also students have only average monthly pocket money of RM873.96 per month from their parents or study loan to support their increasing expenditures. In support, $15 \%$ of them also select utilitarian mall format indicating their intention towards shopping only when it was needed. The finding from the work of Calvo-Porral and Lévy-Mangin (2019) further explained the mix between utilitarian and hedonic characteristics of customers. They found that the utilitarian believers that they called "deal hunters" intended to patronage a mall for window shopping purpose in their quest to find greater bargain, rather than satisfying their emotive sides.

\section{Conclusion}

This research merely focused on the influence of hedonic and utilitarian shopping values towards Malaysian consumer behavioral intention with a special focus on the youth market. The results stated that hedonic and utilitarian shopping values significantly influenced consumer behavioral intention. The outcomes of this research have practical implications on mall developers. Shopping should be designed as an exciting rather than a mundane task for the youth. This could be achieved by creating leisure mall ambience, including high assortment of stores, developing entertainment centers and eating out options in the shopping malls. Nevertheless, for the utilitarian shoppers, the layout of the shopping malls should also be functional in which utilitarian shoppers will be able to navigate their shopping trips in less time and effort. The location of the shopping mall is another concern which will attract the utilitarian shoppers if it is relatively near to the residential areas or in the case of the current research, to 
the campus. However, mall developers must be aware that it is almost impossible to create a shopping experience that will satisfy both the hedonic and utilitarian shoppers at the same time. For that reason, they should take further consideration on the demographic and geographic segmentation of the market they serve.

Since data were collected from university students, this research has less control over the proportion of male and female in the sample. Hence, it is recommended that future studies investigate the effect of gender on consumer buying behavior by performing stratified sampling to ensure equal representation of male and female in the sample. In fact, past researchers connoted that female and male shoppers loyalty were determined by different factors (Haj-Salem, Chebat, Michon, \& Oliveira, 2016).

\section{Acknowledgements}

We would like to thank Dr. Hariyati Ab Wahid from Universiti Pendidikan Sultan Idris for assisting in the data collection phase of this study.

\section{References}

Alavi, S. A., Rezaei, S., Valaei, N., \& Wan Ismail, W. K. (2016). Examining shopping mall consumer decision-making styles, satisfaction and purchase intention. The International Review of Retail, Distribution and Consumer Research, 26(3), 272-303.

Albattat, A., Yajid, M., \& Khatibi, A. (2019). The determination of shopping satisfaction of tourists visiting One Utama shopping mall. Management Science Letters, 9(13), 2291-2304.

Allard, T., Babin, B. J., \& Chebat, J-C. (2009). When income matters: Customers evaluation of shopping malls' hedonic and utilitarian orientations. Journal of Retailing and Consumer Services, 16(1), 40-49.

Babin, B. J., Darden, W. R., \& Griffin, M. (1994). Work and/or fun: measuring hedonic and utilitarian shopping value. Journal of Consumer Research, 20(4), 644-656.

Bakirtas, H., Bakirtas, İ., \& Çetin, M. A. (2015). Effects of utilitarian and hedonic shopping value and consumer satisfaction on consumer behavioral intentions. Ege Akademik Bakış Dergisi, 15(1), 91-98.

Budisantoso, T., Bhati, A., Bradshaw, A., \& Tang, C. M. (2016). Hedonic Shopping Motivation: Does It Really Matter?. In Purnendu Mandal \& John Vong (Eds.), Development of Tourism and the Hospitality Industry in Southeast Asia (pp. 51-64). Singapore: Springer Singapore.

Calvo-Porral, C., \& Lévy-Mangin, J-P. (2019). Profiling shopping mall customers during hard times. Journal of Retailing and Consumer Services, 48, 238-246.

Chebat, J-C., Michon, R., Haj-Salem, N., \& Oliveira, S. (2014). The effects of mall renovation on shopping values, satisfaction and spending behaviour. Journal of retailing and consumer services, 21(4), 610-618.

Chung, Y-S. (2015). Hedonic and utilitarian shopping values in airport shopping behavior. Journal of Air Transport Management, 49, 28-34.

Dalziel, R. C., \& Bevan-Dye, A. L. (2018). Validation of a Hedonic Shopping Motivation Model in the South African Context. International Journal of Business and Management Studies, 10(2), 215-227.

Davis, R., Smith, S. D., \& Lang, B. U. (2017). A comparison of online and offline gender and goal directed shopping online. Journal of Retailing and Consumer Services, 38, 118-125.

El Hedhli, K., Zourrig, H., \& Chebat, J-C. (2016). Shopping well-being: Is it just a matter of pleasure or doing the task? The role of shopper's gender and self-congruity. Journal of Retailing and Consumer Services, 31, 1-13.

El Hedhli, K., Zourrig, H., \& Park, J. (2017). Image transfer from malls to stores and its influence on shopping values and mall patronage: The role of self-congruity. Journal of Retailing and Consumer Services, 39, 208-218.

Elizabeth Lloyd, A., YK Chan, R., SC Yip, L., \& Chan, A. (2014). Time buying and time saving: effects on service convenience and the shopping experience at the mall. Journal of Services Marketing, 28(1), 36-49.

Erkip, F., \& Ozuduru, B. H. (2015). Retail development in Turkey: An account after two decades of shopping malls in the urban scene. Progress in Planning, 102, 1-33.

Evangelista, F., Low, B. K., \& Nguyen, M. T. (2019). How shopping motives, store attributes and demographic factors influence store format choice in Vietnam: A logistic regression analysis. Asia Pacific Journal of Marketing and Logistics. 
Hair, J. F., Black, W. C., Babin, B. J., \& Rolph, E. A. (2014). Multivariate Data Analysis (7th ed.). Essex, England: Pearson Education Limited.

Haj-Salem, N., Chebat, J. C., Michon, R., \& Oliveira, S. (2016). Why male and female shoppers do not see mall loyalty through the same lens? The mediating role of self-congruity. Journal of Business Research, 69(3), 1219-1227.

Hami, A., Fazle, F., \& Emami, F. (2016). Factors affecting people preferences toward environment landscape, case study: shopping mall in Kuala Lumpur. Journal of Current Research in Science, 4(2), 216-225.

Hana, A., \& Norlaile, S. H. (2017). Customer's Assessment of Online Laundry Service. International Journal of Business and Management, 1(2), 174-181.

Hana, A., \& Norlaile, S. H. (2018). Customers' Use Intention of Using Online Laundry Service. International Journal of Business and Management, 2(1), 83-90.

Hirschman, E. C., \& Holbrook, M. B. (1982). Hedonic consumption: emerging concepts, methods and propositions. Journal of Marketing, 46(3), 92-101.

Institut Penyelidikan Belia Malaysia. (2019). Populasi Keseluruhan Penduduk dan Belia Retrieved 24 Sep. 2019, from https://www.ippbm.gov.my/index.php/populasi-keseluruhan-penduduk-dan-belia

Jalil, N. A. A., Fikry, A., \& Zainuddin, A. (2016). E-atmospheric effects on youth intention to revisit a cafe. Procedia Economics and Finance, 37, 497-503.

Joshua, O. O. (2016). Hunger and Malnutrition: Review of Copenhagen Consensus Challenge Paper 2004. American Journal of Social Sciences and Humanities, 1(2), 85-99.

Kaihatu, T. S., \& Spence, M. T. (2016). The relationship between shopping mall image and congruity on customer behaviour: Evidence from Indonesia. Australasian Marketing Journal (AMJ), 24(2), 141-145.

Kesari, B., \& Atulkar, S. (2016). Satisfaction of mall shoppers: A study on perceived utilitarian and hedonic shopping values. Journal of Retailing and Consumer services, 31, 22-31.

Krejcie, R. V., \& Morgan, D. W. (1970). Determining sample size for research activities. Educational and Psychological Measurement, 30(3), 607-610.

Kumaraswamy, S., Ebrahim, R. H., \& Wan Mohammad, W. M. (2019). Dividend policy and stock price volatility in Indian capital market. Entrepreneurship and Sustainability Issues, 7(2), 862-874.

Lim, K. C., Ramli, K. I., Yusof, N. S., \& Cheah, S. T. (2015). Examining young Malaysians travel behavior and expenditure patterns in domestic tourism.

Manwaluddin, I. I., Teng, L. C., Johari, A. A. H. A., Baharudin, M. F., \& Suhaimi, M. H. (2018). Factors That Affect Online Shopping Behaviour on E-Business Platform Towards Generation Y in Malaysia. Journal of Information, $3(9), 50-65$.

Mejdoub, H., \& Arab, M. B. (2017). A multivariate analysis for risk capital estimation in insurance industry: Vine Copulas. Asian Development Policy Review, 5(2), 100-119.

Michon, R., Chebat, J-C., Yu, H., \& Lemarié, L. (2015). Fashion orientation, shopping mall environment, and patronage intentions: a study of female fashion shoppers. Journal of Fashion Marketing and Management, 19(1), 3-21.

Mustafa, S. A. (2016). The Effective Strategies in Companies' Performance Using the Partial Least Squares Approach. International Journal of Economics, Business and Management Studies, 3(2), 94-101.

Nunnally, J. C. (1978). Psychometric theory (2nd ed.). New York: McGraw-Hill.

Onuoha, B. C., Umoh, E. D., \& Ufomba, H. (2017). The Impact of the Politics of Privatization and Commercialization of Public Enterprises in Nigeria on the Level of Productivity and Economic Viability: The Case of Alscon and Nitel. Asian Development Policy Review, 5(1), 43-55.

Parakhonyak, A., \& Titova, M. (2018). Shopping malls, platforms and consumer search. International Journal of Industrial Organization, 58, 183-213.

Pentecost, R., Donoghue, S., \& Thaichon, P. (2019). Emerging from my youth-intra-cohort segmentation. International Journal of Retail \& Distribution Management, 47(5), 571-588.

Prashar, S., Singh, H., Parsad, C., \& Vijay, T. S. (2017). Predicting Indian shoppers' malls loyalty behaviour. Vikalpa, 
42(4), 234-250.

Rahman, O., Wong, K. K-K., \& Yu, H. (2016). The effects of mall personality and fashion orientation on shopping value and mall patronage intension. Journal of Retailing and Consumer Services, 28, 155-164.

Ramlan, W. K., Nga, J. L. H., Idris, R., \& Jinideh, D. D. J. (2018). Corak Perbelanjaan dan Kemampuan Berbelanja Golongan Belia Malaysia. Malaysian Journal of Youth Studies, 18, 7-28.

Rusomyo, R., Junlin, H., \& Mangare, C. (2017). The Role of Social Networks as Survival Strategies in Agro-Pastoral Communities in Arid And Semi-Arid Lands in Tanzania. Asian Development Policy Review, 5(2), 90-99.

Said, I., Gambo, N., \& Ismail, R. (2016). An evaluation into the architectural factors attracting customers to Malaysian shopping malls. Journal of Business and Retail Management Research, 11(1).

Schouten, M.J. (2019). Undoing gender inequalities: insights from the Portuguese perspective. Insights into Regional Development, (2), 85-98.

Stoel, L., Wickliffe, V., \& Lee, K. H. (2004). Attribute beliefs and spending as antecedents to shopping value. Journal of Business Research, 57(10), 1067-1073.

Touitou, T. C. (2016). Does Amnesty Programme in Niger Delta have Economic Benefit to Nigeria?. Asian Business Research Journal, 1, 1-7.

Vukadin, A., Wongkitrungrueng, A., \& Assarut, N. (2018). When art meets mall: Impact on shopper responses. Journal of Product \& Brand Management, 27(3), 277-293.

Waheed, A., Yang, J., Ahmed, Z., Rafique, K., \& Ashfaq, M. (2017). Is marketing limited to promotional activities? The concept of marketing: A concise review of the literature. Asian Development Policy Review, 5(1), 56-69.

Yeboah, P. O., \& Addaney, M. (2016). Corporate rebranding and performance of financial institutions in Ghana. Journal of Asian Business Strategy, 6(7), 150-166. 